\title{
THE EFFECTS OF INDUCED MALARIA, ACUTE STARVATION AND SEMI-STARVATION ON THE ELECTROPHORETIC DIAGRAM OF THE SERUM PROTEINS OF NORMAL YOUNG MEN ${ }^{1}$
}

\author{
By HENRY LONGSTREET TAYLOR, OLAF MICKELSEN, AND ANCEL KEYS
}

(From the Laboratory of Physiological Hygiene, University of Minnesota, Minneapolis)

(Received for publication September 15, 1948)

During the last ten years, the technique for the electrophoretic analysis of serum proteins, originally described by Tiselius (1), has been standardized and a large number of important conditions have been studied. Luetscher (2) has reviewed this work and pointed out that the common denominator of all disease processes studied has been a relative decrease in the albumin fraction. Both acute and chronic infections produce an increase in the alpha globulin fraction which is often accompanied by an increase in the gamma globulin fraction. Chronic noninfectious processes such as ulcer or cancer also are accompanied by an increase in one or both of the alpha globulin fractions. Chow (3) has demonstrated that there exists a negative correlation between the relative amounts of serum albumin and the combined alpha globulins in disease states such as tuberculosis, ulcer and malnutrition. It has been shown that the characteristic response to protein depletion in the $\operatorname{dog}(4,5)$ is also a decrease in albumin and an increase in the alpha globulins. Since this same change occurs in disease Chow has quite properly raised the question as to whether it is a response to the disease state or whether it is the result of the protein depletion which is common to these diseases.

1 The work reported here was supported in part by The Brethren Service Committee, Elgin, Illinois; The Service Committee of The Society of Friends, Philadelphia; The Mennonites Central Committee, Akron, Pennsylvania; The John and Mary R. Markle Foundation, New York; The Sugar Research Foundation, New York; The National Dairy Council, operating on behalf of The American Dairy Association, Chicago; and The Home Missions Board of the Unitarian Society, Boston. In addition, support was provided under the terms of a contract, recommended by The Committee on Medical Research, between The Regents of the University of Minnesota and the Office of Scientific Research and Development. During the last phases of the work on semi-starvation, this contract was transferred to the Office of the Surgeon General, U. S. Army.
Experiments in this laboratory on the effects of induced malaria, of acute starvation and of semi-starvation on human volunteers provided an opportunity to study these questions in controlled and uncomplicated situations. Data from these experiments which throw some light on the relationship of protein depletion to serum protein composition during disease and starvation form the basis for this report.

\section{CONDITIONS AND MATERIALS}

All the subjects were males between the ages of 18 and 34 years and were members of Civilian Public Service. A careful medical examination failed to disclose signs of disease or abnormality when the men were admitted to the laboratory dormitory.

Eleven of these men took part in a long-term dietary experiment in which caloric and thiamine intake were carefully controlled. These diets were adequate in all known dietary constituents. This group of men was subjected at different times to both the stress of malarial fever and five days when they received no food. Ample time was allowed between the starvation stress and the induction of malaria for the subjects to recover completely from the effects of going without food.

These volunteers were inoculated with the McCoy strain of tertian malaria and all of them developed the active disease. After five to eight paroxysms and an average of 193 degree-hours of body temperature above $101^{\circ} \mathrm{F}$., the malarial fever was terminated with quinine sulfate. Further details of this work will be presented elsewhere (6). Blood was drawn with the men in the fasting state the day before inoculation and again at the end of the febrile period. Plasma volumes were determined on the same day using the blue dye, T 1824. The concentration of the dye was determined by extrapolation of values obtained at 20,30 and 40 minutes after the injection of the dye. The plasma volumes were calculated according to the procedure of Gibson and Evans (7).

Four of the 11 men were also subjected to five days of simultaneous starvation and hard work. The regimen of activity was so designed that the men expended 4,500 Calories a day during the fast. During this period the men lost an average of 13.8 pounds or 9 per cent of the initial body weight. Similar experiments which lasted for a shorter period of time have been described previously (8). Blood samples were drawn the morning of 
TABLE I

The electrophoretic components of the serum proteins before and after a bout of induced malaria

\begin{tabular}{|c|c|c|c|c|c|c|c|c|c|c|c|c|}
\hline \multirow{2}{*}{$\begin{array}{l}\text { Prote1n } \\
\text { Praction }\end{array}$} & \multicolumn{4}{|c|}{ Por cent of Iotal Petterr } & \multicolumn{4}{|c|}{ Creas per 100 cr. Serum } & \multicolumn{4}{|c|}{ Clrculat1no Protelas, freme } \\
\hline & $\begin{array}{l}\text { Before } \\
\text { malaria }\end{array}$ & $\begin{array}{l}\text { after } \\
\text { aelaria }\end{array}$ & Change & $\begin{array}{l}\text { per cent } \\
\text { Cizange }\end{array}$ & $\begin{array}{l}\text { Before } \\
\text { malaria }\end{array}$ & $\begin{array}{c}\text { Aftor } \\
\text { malaria }\end{array}$ & Change & $\begin{array}{l}\text { por cont } \\
\text { Change }\end{array}$ & $\begin{array}{l}\text { Before } \\
\text { melarla }\end{array}$ & $\begin{array}{c}\text { after } \\
\text { malarla }\end{array}$ & Change & $\begin{array}{l}\text { Por cont } \\
\text { Change }\end{array}$ \\
\hline$\Delta 18$. & 64.2 & 55.9 & -8.3 & 12.9 & 4.38 & 3.79 & -0.59 & 23.4 & 148.1 & 127.5 & -21.6 & 14.5 \\
\hline Olob. & 35.8 & 44.2 & +8.3 & 23.2 & 2.44 & 2.97 & +0.53 & 2.7 & 82.5 & 99.9 & +17.4 & 2. 0 \\
\hline Alphe 1 & 4.2 & 6.8 & +2.7 & 65.9 & 0.28 & 0.46 & +0.18 & 64.3 & 9.5 & 15.4 & 4.9 & 62.1 \\
\hline Alphe 2 & 7.7 & 8.1 & +0.4 & 5.2 & 0.53 & 0.55 & +0.02 & 3.7 & 17.9 & 28.5 & -0.6 & 3.3 \\
\hline Bote & 21.4 & 13.7 & +2.3 & 20.2 & 0.77 & 0.93 & +0.16 & 20.7 & 26.1 & 32.3 & +5.2 & 20.0 \\
\hline Camma & 12.7 & 15.3 & +2.6 & 20.5 & 0.86 & 1.03 & 40.17 & 19.7 & 29.1 & 34.6 & +5.5 & 18.9 \\
\hline
\end{tabular}

The various fractions are expressed as per cent of the total electrophoretic pattern, as grams per 100 cc. of serum and as grams in the serum volume. Mean values from 11 men.

the first day of fasting and at the end of the fifth day just before food was taken.

Another group of six men was studied during a sixmonth period of semi-starvation and at intervals during 32 weeks of recovery. Three additional starvation subjects were studied during the first 12 weeks of recovery. The diet consumed during the period of semi-starvation was an European type of famine diet which averaged 1,654 Calories per day and contained 59 grams of protein; the general plan of the experiment has been presented elsewhere (9) and a few special aspects have been described $(10,11)$. The six months of restricted diet resulted in a 24 per cent loss of body weight and the development of the typical signs and symptoms of starvation, i.e., fatigue, weakness, depression, polyuria, bradycardia and edema. During refeeding the weight of the men reported here was regained slowly. After six weeks only 15 per cent of the lost weight had been regained. Corresponding weight gains and time intervals were 12 weeks, 40 per cent; 20 weeks, 104 per cent; and 32 weeks, 107 per cent. . Plasma volumes were determined on some of these men during both the semi-starvation and recovery period using the blue dye technique. The details have been presented elsewhere (10).

The electrophoresis was carried out in the Tiselius apparatus according to the technique described by Longsworth (12). A $90 \mathrm{~mm}$. center section cell was employed to give good resolution of the pattern. Samples of sera were diluted with veronal buffer with an ionic strength and $\mathrm{pH}$ of 0.1 and 8.6 , respectively. This mixture was dialyzed against the buffer in the cold $\left(4^{\circ} \mathrm{C}\right.$.) for two days and then placed in the electrophoresis cell. The concentration of the serum protein at this time was between 2.5 and 3 grams per $100 \mathrm{ml}$. of solution. The patterns were analyzed by measuring the area under each peak with a planimeter after the area for each peak had been designated by the method of Tiselius and Kabat (13). The areas of the various components were measured on both the ascending and descending patterns and these were then averaged. Serum protein concentrations were determined by the micro-Kjeldahl procedure of Keys
(14) and the concentrations of the various electrophoretic components were calculated assuming a constant refractive index and nitrogen factor for all fractions, an assumption which does not lead to large errors in normal serum (15).

\section{RESULTS}

\section{The effects of malaria}

The effect of malaria on the distribution of the electrophoretic components of the serum proteins of the 11 subjects is summarized in Table I. It will be noted that there was no essential change in the concentration of total protein. There was

TABLE II

The comparison of the degree-hours of fever above $101^{\circ} \mathrm{F}$. and the changes in terms of per cent of total pattern of the albumin, $\alpha_{1}$, beta and gamma fractions of the electrophoretic pattern

\begin{tabular}{|c|c|c|c|c|c|}
\hline $\begin{array}{c}\text { Subject } \\
\text { Ulumber }\end{array}$ & $\begin{array}{l}\text { Degree } \\
\text { Bours }\end{array}$ & Alb. & Alpha 2 & Bets & Games \\
\hline 19 & 147 & -2.4 & 2.5 & 0.5 & -0.3 \\
18 & 164 & -13.5 & 1.8 & 3.4 & 6.9 \\
10 & 172 & -13.5 & 3.0 & 3.1 & 8.2 \\
16 & 179 & -8.0 & 2.0 & 2.5 & 3.2 \\
20 & 185 & -3.5 & 3.0 & 1.5 & 1.9 \\
9 & 193 & -7.1 & 1.1 & 2.1 & 2.8 \\
6 & 196 & -8.5 & 3.3 & 1.5 & 2.7 \\
7 & 197 & -8.3 & 2.7 & 5.7 & 6.5 \\
17 & 198 & -4.7 & 2.9 & 3.5 & -1.8 \\
15 & 216 & -8.0 & 3.7 & 1.8 & 2.5 \\
11 & 221 & -8.4 & 4.0 & 1.5 & 1.9 \\
\hline
\end{tabular}

The subjects are arranged in order of increasing degree-hours. 


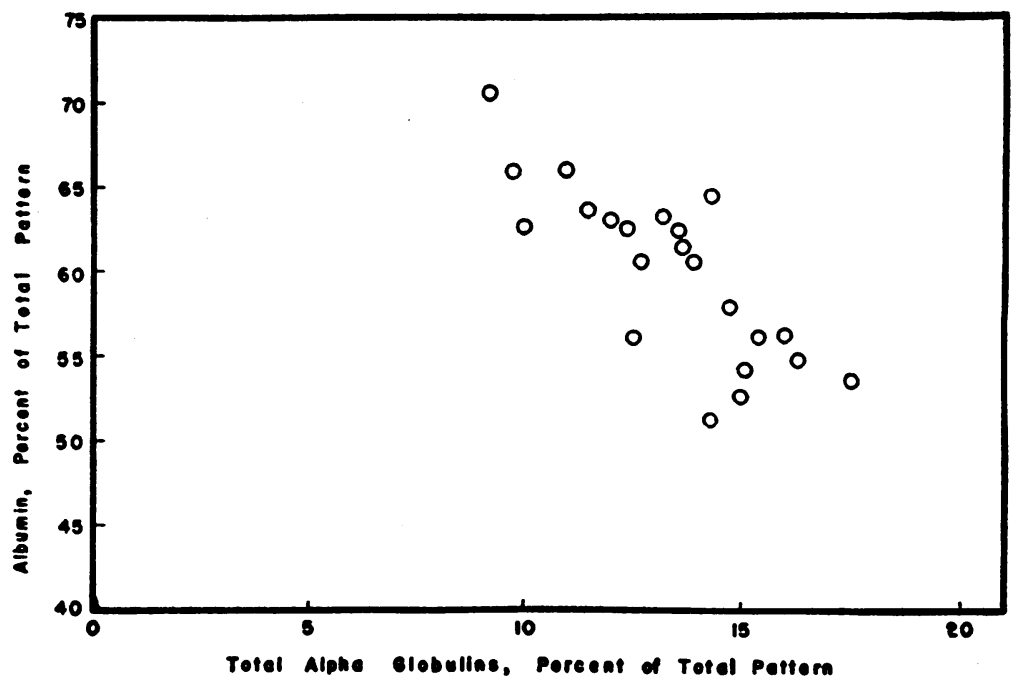

Fig. 1. The Relationship Between the Albumin Expressed as Per Cent of Total Electrophoretic Pattern and the Sum of the $\alpha_{1}$ and $\alpha_{2}$ Globulins Expressed in the Same Units

Data are taken from the analysis of the sera of 11 men before and after a bout of malaria.

also no change in the circulating serum volumes of this group which averaged $3,383 \pm 287 \mathrm{cc}$. before innoculation with plasmodium vivax and $3,365 \mathrm{cc} . \pm 307 \mathrm{cc}$. after the last paroxysm. There was a 12 per cent reduction in the relative amount of albumin which represents an actual decrease in concentration and a loss of circulating albumin.

The relative areas of the $\alpha_{1}$ and $\alpha_{2}$ fractions were averaged and plotted against that of albumin. The results are presented in Figure 1. The product-moment correlation is 0.72 , a figure which is regarded by Snedecor as a significant correlation.

The extent of the changes in the electrophoretic pattern was compared with the number of degree-hours of fever above $101^{\circ} \mathrm{F}$. The data are presented in Table II. The alpha globulin appears to be the only component which showed a change related to the number of degree-hours of fever above $101^{\circ} \mathrm{F}$. The product-moment correlation is 0.54 between degree-hours and the percentage change of $\alpha_{1}$ globulin.

TABLE III

The effect of $4 \frac{1}{2}$ days of starvation and hard work on the electrophoretic diagrams of four men

\begin{tabular}{|c|c|c|c|c|c|c|c|c|c|c|c|c|}
\hline & Total 2 & oteins & & 16. & Alphe 1 & Glob. & Alpha 2 & OlOb. & Beta & 3100 . & Camma $G$ & $10 b$. \\
\hline $\begin{array}{l}\text { Subject } \\
\text { momber }\end{array}$ & Before & After & Before & Aeter & Sefore & After & Before & After & Before & After & Before & Aster \\
\hline 12 & 6.99 & 7.70 & 63.0 & 67.8 & 3.7 & 3.2 & 5.7 & 4.4 & 12.0 & 10.6 & 15.6 & 14.0 \\
\hline 6 & 7.02 & 8.81 & 64.0 & 67.0 & 3.3 & 2.7 & 6.2 & 5.0 & 21.0 & 9.5 & 15.5 & 15.8 \\
\hline 28 & 6.90 & 7.62 & 63.8 & 66.2 & 4.6 & 3.8 & 7.7 & 6.4 & 20.1 & 9.3 & 13.8 & 24.3 \\
\hline 7 & 6.68 & 7.30 & 65.5 & 68.5 & 3.9 & 3.4 & 8.0 & 6.6 & 13.6 & 12.6 & 9.0 & 8.9 \\
\hline Mean & 6.90 & 7.86 & 64.1 & 67.4 & 3.9 & 3.3 & 6.9 & 5.6 & 11.7 & 10.5 & 23.4 & 13.2 \\
\hline Change & & +0.96 & & $+3 \cdot 3$ & & -0.6 & & -1.3 & & -1.2 & & -0.2 \\
\hline
\end{tabular}

The protein concentration is expressed as grams per $100 \mathrm{cc}$. of serum and the relative amounts of the various electrophoretic fractions as per cent of the total pattern. 
TABLE IV

The electrophoretic analysis of the sera of two men demonstrating the effect of 24 weeks of semi-starvation

\begin{tabular}{|c|c|c|c|c|c|c|c|c|c|c|c|c|c|}
\hline & & \multicolumn{6}{|c|}{ Subjoct Eo. 122} & \multicolumn{6}{|c|}{ Subjoct t5o. 123} \\
\hline \multicolumn{2}{|c|}{ Perlod } & Oontrol & s12 & 324 & 86 & m2 & 232 & Control & s12 & 524 & 16 & n2 & 232 \\
\hline \multirow{2}{*}{\multicolumn{2}{|c|}{$\begin{array}{c}\text { Sotal protelne } \\
\text { one. } / 200 \propto 0 . \\
1 / 0\end{array}$}} & 6.89 & 7.10 & 5.88 & 6.78 & 7.10 & 6.28 & 6.99 & 7.18 & 6.16 & 6.43 & 7.24 & 6.60 \\
\hline & & 1.70 & 2.30 & 1.70 & 2.33 & 1.95 & 1.65 & 1.76 & 2.40 & 1.88 & 2.00 & 1.92 & 2.58 \\
\hline E & $\Delta 18$. & 62.8 & 69.6 & 63.0 & 70.0 & 66.2 & 62.2 & 63.7 & 70.6 & 65.4 & 66.7 & 65.5 & 61.2 \\
\hline ă & Alphe I & 4.9 & 3.5 & 4.7 & 3.3 & 4.2 & 4.3 & 4.4 & 3.2 & 3.2 & 3.3 & 3.3 & 4.2 \\
\hline$\vec{d}$ & Alpha 2 & 8.4 & 7.7 & 9.7 & 7.1 & 8.0 & 8.4 & 7.5 & 6.4 & 7.5 & 7.0 & 7.2 & 9.2 \\
\hline 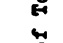 & Bote & 22.8 & 20.5 & 12.9 & 11.6 & 23.0 & 25.2 & 21.2 & 9.9 & 23.7 & 23.2 & 23.1 & 25.0 \\
\hline 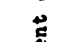 & Gamma & 22.1 & 3.7 & 9.7 & 8.0 & 8.6 & 9.9 & 13.1 & 9.9 & 10.2 & 9.8 & 10.9 & 20.5 \\
\hline
\end{tabular}

The analysis is presented for the control period, after 12 and 24 weeks of semi-starvation and after six, 12 and 32 weeks of rehabilitation.

\section{The effects of acute starvation}

The results of acute starvation are presented in Table III. There was a small but definite increase in the albumin fraction. This was accompanied by a decrease in both of the alpha globulins. The total protein concentration was increased by 14 per cent, a consequence presumably of the mild acidosis which accompanied the fast.

\section{The effects of semi-starvation}

Complete data are available on two men during the period of semi-starvation and recovery. This is presented in Table IV. There was an increase in the albumin fraction after 12 weeks of semistarvation when these men had lost 18 per cent of their original body weight. The relative amount of albumin dropped somewhat after 24 weeks of semi-starvation when it was slightly above the value for the control period. During early rehabilitation it increased again slightly and then returned to normal by the end of 20 weeks when the original body weight had been recovered. There was a small decrease in the gamma globulin which was apparent at 12 weeks of semistarvation and showed no further change after 24 weeks. It should be noted, however, that the gamma globulin had not reached control levels at the end of 32 weeks of recovery. The changes in the globulins of intermediate mobility do not appear to be significant except for the elevation of the beta fraction above the control levels at the end of recovery.
It had been planned to study six men throughout the course of the experiment but four samples of serum drawn at the end of semi-starvation were lost in an unfortunate refrigeration accident. The available data on these six men are presented in Table $\mathrm{V}$. The results are similar and confirmatory to those found in Table IV.

Since the plasma volume tends to increase during starvation (10), the calculation of the total circulating protein clarifies the interpretation of the electrophoretic pattern. Plasma volumes were available for subjects 122 and 123 at the beginning and end of the semi-starvation pe-

TABLE V

Mcan values from electrophoretic analyses of blood serum

\begin{tabular}{|c|c|c|c|c|c|c|c|c|}
\hline Period & Potal & $1 / 0$ & A2b. & Plob. & Alphe & $\begin{array}{l}\text { Potal Pn } \\
\text { Alpha } 2\end{array}$ & Bete & Ganses \\
\hline Control & 6.90 & 2.54 & 64.7 & 35.3 & 4.4 & 7.7 & 10.9 & 12.3 \\
\hline s12 & 7.25 & 2.31 & 69.5 & 30.5 & 3.3 & 6.8 & 20.2 & 10.2 \\
\hline 86 & 6.58 & 2.13 & 67.7 & 32.3 & 3.5 & 7.1 & 11.9 & 9.7 \\
\hline $\mathbf{n 2}$ & 7.24 & 2.02 & 66.6 & 33.4 & 3.5 & 7.3 & 12.2 & 10.4 \\
\hline 220 & 6.58 & $1 . n$ & 62.8 & 37.2 & 4.3 & 8.0 & 14.1 & 10.9 \\
\hline 144 & 6.47 & 2.62 & 62.6 & 38.4 & 4.2 & 8.2 & 24.9 & 21.2 \\
\hline 30 Yormal. & 7.01 & 1.72 & 63.0 & 37.0 & 4.2 & 8.0 & 12.0 & 22.9 \\
\hline Stand. Dar. & 0.35 & 0.22 & 2.81 & & 0.55 & 0.96 & 1.72 & 2.02 \\
\hline
\end{tabular}

Results from the same six men are averaged for control, after 12 weeks of semi-starvation (S12) and after six and 12 weeks of rehabilitation (R6 and R12). Values for four men are averaged for the periods R20 and R34 (after 20 and 34 weeks of rehabilitation). For normal comparison, mean values and their standard deviations are given for 30 normal men. Values are in grams per $100 \mathrm{cc}$. for total serum proteins and as per cent of total proteins represented by the several fractions. 
TABLE VI

The plasma volumes (in cubic centimeters) and the circulating fractions of the serum proteins (in grams) of two men before $(C)$ and after 24 weeks of semi-starvation (S24)

\begin{tabular}{|c|c|c|c|c|c|c|c|c|}
\hline $\begin{array}{l}\text { Subject } \\
\text { Iumber }\end{array}$ & Perlod & $\begin{array}{l}\text { Plasma } \\
\text { Vol. }\end{array}$ & Alb. & $\begin{array}{l}\text { ireanls } \\
\text { Clob. }\end{array}$ & $\begin{array}{l}\text { Pente } \\
\text { alpha } ?\end{array}$ & $\begin{array}{l}\text { Dreactit } \\
\text { ilpha } 2\end{array}$ & Beta & Camms \\
\hline \multirow[t]{2}{*}{122} & C & 2746 & 218.9 & 70.3 & 9.3 & 15.9 & 22.4 & 22.8 \\
\hline & s24 & 3206 & 138.8 & 81.8 & 10.2 & 21.5 & 28.5 & 21.5 \\
\hline \multirow[t]{2}{*}{123} & C & 3059 & 136.1 & 77.7 & 9.5 & 16.2 & 23.8 & 28.1 \\
\hline & s24 & 3404 & 137.2 & 72.5 & 6.8 & 15.6 & 28.5 & 21.4 \\
\hline 17 Dormals & & 3249 & 140.7 & 79.1 & 9.4 & 17.2 & 24.9 & 27.7 \\
\hline Stand. Dev. & & \pm 305 & \pm 13.5 & \pm 10.0 & \pm 1.6 & \pm 2.5 & \pm 3.3 & \pm 5.6 \\
\hline
\end{tabular}

For comparison the values of the same variable found in a group of 17 normals are presented along with their standard deviations.

riod. The circulating protein fractions in grams are presented in Table VI along with data for 17 normal young men. It will be noted that the only consistent changes were an increase in the beta globulin and a small decrease in the gamma fraction. The total circulating serum protein fractions for four men in the control period and after 12 weeks of semi-starvation are presented in Table VII. A definite increase in the albumin fraction and a small decrease in the circulating $\alpha_{1}$ and gamma globulins are shown in this table.
Plasma volumes and electrophoretic analyses of sera were available on three additional men during the 12 weeks of recovery. These data are presented in Table VIII to illustrate the situation in early recovery. By $\mathrm{R} 6$ these men, who were in the group fed a "good" rehabilitation diet, had regained 20 per cent and at R12 they had recovered 53 per cent of the weight lost during semistarvation. It will be noted that the decrease in the albumin fraction between R6 and R12 is due entirely to the data obtained from one man and

TABLE VII

The plasma volumes (in cubic centimeters) and the circulating fractions of the serum proteins (in grams) of four men before $(C)$ and after 12 weeks of semi-starvation (S12)

\begin{tabular}{|c|c|c|c|c|c|c|c|c|}
\hline \multirow[b]{2}{*}{ Porlod } & \multirow{2}{*}{$\begin{array}{c}\text { Subjoct } \\
\text { Ifo. }\end{array}$} & \multirow{2}{*}{$\begin{array}{l}\text { Plaema } \\
\text { Polume }\end{array}$} & \multicolumn{6}{|c|}{ C1rculating Prote1n Practions } \\
\hline & & & בLb. & G106. & Inter I & Iphe 2 & Beta & Wingent \\
\hline \multirow{6}{*}{ c } & 123 & 3059 & 136.1 & 77.6 & 9.5 & 15.9 & 23.9 & 28.1 \\
\hline & 119 & 2599 & 116.2 & 59.5 & 7.0 & 15.6 & 19.5 & 17.4 \\
\hline & 129 & 3316 & 142.6 & 67.6 & 9.0 & 16.2 & 19.9 & 22.5 \\
\hline & 26 & 3201 & 147.2 & 83.5 & 9.9 & 18.2 & 25.6 & 29.8 \\
\hline & mean. & 3044 & 135.5 & 72.1 & 8.8 & 16.5 & 22.2 & 24.3 \\
\hline & 123 & 2936 & 248.5 & 62.2 & 6.8. & 13.5 & 20.9 & 2.1 \\
\hline \multirow[t]{4}{*}{ s12 } & 119 & 2504 & 118.9 & 56.8 & 5.8 & 25.5 & 28.8 & 16.8 \\
\hline & 129 & 3508 & 185.2 & 65.3 & 9.1 & 27.5 & 22.5 & 16.1 \\
\hline & 26 & 3381 & 274.5 & 86.6 & 7.8 & 23.9 & 28.7 & 36.2 \\
\hline & mean. & 3082 & 156.8 & 67.7 & 7.3 & 15.1 & 22.7 & 22.5 \\
\hline
\end{tabular}


TABLE VIII

The plasma volume (in cubic centimeters) and the circulating fractions of the serum proteins (in grams) of three men after six weeks (R6) and 12 weeks (R12) of recovery from semi-starvation

\begin{tabular}{|c|c|c|c|c|c|c|c|c|}
\hline \multirow{2}{*}{ Period } & \multirow{2}{*}{$\begin{array}{c}\text { Subject } \\
\text { Ho. }\end{array}$} & \multirow{2}{*}{$\begin{array}{l}\text { Plasma } \\
\text { Volume }\end{array}$} & \multicolumn{6}{|c|}{ C1roulatine Proteln Sractions } \\
\hline & & & 418. & aob & Aphe 1 & Nphe 2 & Bota & Cama \\
\hline \multirow[t]{4}{*}{86} & 104 & 2972 & 126.6 & 64.8 & 6.2 & 18.4 & 23.2 & 17.0 \\
\hline & 109 & 4182 & 173.9 & 98.3 & 10.0 & 21.3 & 33.9 & 33.0 \\
\hline & 112 & 2695 & 121.8 & 77.2 & 7.0 & 18.3 & 26.9 & 24.8 \\
\hline & mean & 3283 & 140.7 & 80.1 & 7.8 & 19.3 & 28.0 & 24.9 \\
\hline \multirow[t]{4}{*}{ m2 } & 104 & 2700 & 121.0 & 79.9 & 9.2 & 25.1 & 25.7 & 29.7 \\
\hline & 109 & 3442 & 148.0 & 84.0 & 8.3 & 15.8 & 31.7 & 28.2 \\
\hline & 212 & 2907 & 123.0 & 86.3 & 7.3 & 21.2 & 32.0 & 25.9 \\
\hline & moan & 3016 & 131.0 & 83.3 & 8.3 & 20.7 & 29.8 & 24.6 \\
\hline
\end{tabular}

For extent of recovery from the starved state see text.

that no change occurred in the total circulating gamma globulin.

\section{DISCUSSION}

The effects of malaria on the electrophoretic pattern confirm the negative correlation between the relative concentration of albumin and that of the alpha globulins reported by Chow (3). Malaria can no longer be regarded as an exception to the rule that acute infectious disease is accompanied by an increase in the alpha globulins.

It may be noted that when the total amounts of the various fractions in the circulation are calculated from the plasma volumes, albumin appears to be lost from the circulation and that there are definite additions to some of the globulin fractions. The effect of malaria on the electrophoretic pattern appears to differ from some other diseases such as scarlet fever (16) and rheumatic fever (16) in that no increase in the $\alpha_{2}$ globulin accompanied the $\alpha_{1}$ rise. Dole (17) has shown that attacks of relapsing malaria do not produce the increase in $\alpha_{1}$ globulin reported here. The absence of this response in the malaria patient who has had several bouts with the disease might appear to be an adaptation to recurring stress.

Guttman et al. (18) studied the effects of malarial fever in syphilitic patients. These investigators used a phosphate buffer at $\mathrm{pH} 7.4$ which does not separate $\alpha_{1}$ globulin from the albumin fraction and this fact presumably accounts for their failure to find any changes in the alpha globulins.

The decrease in albumin and the increase in alpha globulins which have been observed in many acute infectious diseases are not explicable as a result of a simple negative nitrogen balance such as is produced by a caloric deficit. The changes noted during malaria here are similar to those seen in pneumonia (19), scarlet fever (16), rheumatic fever (16), and tonsillitis (20). In contrast, no such changes were seen in acute starvation in spite of the fact that the subjects in the latter experiments lost roughly 50 grams of nitrogen each. This protein loss is comparable to that reported for some acute infectious diseases, including pneumonia and malaria $(21,22)$.

We have noted that, in our studies on malaria, there was little or no relation between the changes in albumin concentration and the number of hours of fever above $101^{\circ} \mathrm{F}$. This is in contrast to reports, based on salting out with sodium sulfate, that the depression of the albumin concentration is related to the intensity of the malarial fever in both men (23) and monkeys (24). The difference may be related to the severity and duration of the disease; the malaria here was relatively mild and of short duration. However, our data indicate that the change in $\alpha_{1}$ globulin is a more sensitive index to the severity of the disease than is the change in albumin content.

The results of the Minnesota semi-starvation 
experiment clearly demonstrate that protein depletion due to simple caloric undernutrition does not explain the decreased relative albumin and increased alpha globulins shown in the electrophoretic patterns of sera from patients suffering from chronic debilitating diseases such as tuberculosis (25), ulcer (3), cancer (25) and rheumatoid arthritis (26). There can be no question that the subjects of the Minnesota starvation experiment were badly depleted of tissue protein. Corrections of the body weight loss (to be discussed elsewhere [27]) for changes in fat by the specific gravity method, for changes in extracellular water by the NASCN method and for changes in bone salt by $\mathrm{X}$-ray density techniques indicate that the body weight loss underestimated the loss of active tissue, i.e., more than 24 per cent of the original protein-containing tissues of the body were lost by these men.

It is apparent, then, that the alterations in the electrophoretic pattern of the serum proteins in the acute and chronic diseases mentioned above are not the results of protein depletion produced simply by a negative caloric balance. The question may be raised as to whether the "toxic destruction" of body protein can account for the picture in these diseases. The so-called catabolic phase (28) is defined empirically as a negative nitrogen balance which will not respond to an additional intake of calories or protein.

At the present time, the evidence is insufficient to decide whether the catabolic phase of protein metabolism is causally related to the characteristic alterations in the patterns seen in various diseases. Several facts suggest that the pattern changes are independent of this type of nitrogen loss. The negative nitrogen balance in tuberculosis, a disease which produces the alterations in pattern described above, is easily corrected by an increased intake of calories and protein (29). In addition, Peters (28) has presented evidence that the serum albumins, determined by the sodium sulfate technique, may increase in infectious diseases in spite of a markedly negative nitrogen balance. Finally, the same author states that after surgery the albumin concentration may decrease before the negative nitrogen balance becomes apparent.

The possibility cannot be ignored that the relatively decreased albumin and increased alpha globulins observed in many diseases is a response to a certain type of injury and is independent of nitrogen loss over a wide range. It should be clearly understood that we are not denying that extreme protein depletion, i.e., protein depletion resulting in more than 24 per cent weight loss, may result in decreased relative albumin concentration which may or may not be accompanied by a relative increase in the alpha globulin.

It is frequently stated that protein depletion results in a lowered resistance to infection (30). It is of interest, therefore, that the protein depletion produced in the Minnesota experiment resulted in only minimal reduction of circulating gamma globulins. While there is much evidence to indicate that the majority of circulating antibodies are found in the gamma globulin fraction (31), it has not been shown that gamma globulin is made up entirely of antibodies. Therefore, the small losses observed in semi-starvation in man do not necessarily represent depletion of circulating antibodies.

\section{SUMMARY AND CONCLUSIONS}

1. The sera of 12 normal young men were examined by the moving boundary method of electrophoresis before and after a bout of induced malaria. The malarial fever was allowed to run through five to eight paroxysms and an average of 193 hours over $101^{\circ} \mathrm{F}$.

2. Changes in a given electrophoretic fraction after malaria were of the same order of magnitude regardless of whether they were expressed as per cent of total pattern, grams per $100 \mathrm{cc}$. of solution or as total circulating proteins. The albumin fraction decreased 14.5 per cent while the $\alpha_{1}$, beta and gamma globulins increased 62, 20 and 19 per cent, respectively.

3. The extent of the change in the $\alpha_{1}$ globulin fraction after malaria more closely paralleled the number of degree-hours of fever over $101^{\circ} \mathrm{F}$. than did the changes in any other fraction of the serum proteins.

4. Four men underwent acute starvation with hard work for five days which resulted in a 9 per cent loss of body weight. Electrophoretic analysis of the sera of these men before and after acute starvation demonstrated no important change other than a general increase in concentration due to a mild dehydration. 
5. Nine subjects took part in a semi-starvation experiment which produced a 24 per cent loss of weight in the course of six months and the classical symptoms of famine, i.e., weakness, fatigue, depression, bradycardia, polyuria and edema. The sera of two of these men were examined in the electrophoresis apparatus six times before and throughout both semi-starvation and recovery. The sera of the other seven men were examined at less frequent intervals. It was possible to calculate circulating plasma protein fractions for a number of these men.

6. The serum albumin fraction showed definite increases above normal after 12 weeks of semistarvation and a loss of 18 per cent of the body weight. This was not accompanied by significant increases in other fractions. After 24 weeks of semi-starvation the albumin fraction had returned to normal. The albumin fraction was not depressed below normal at any time during the experiment.

7. Changes in the globulin fractions were minimal except for a definite increase in the beta fraction at the end of recovery when the men were a little overweight.

8. It is concluded that there are no changes in the electrophoretic diagram which are specifically characteristic of caloric undernutrition whether produced by complete starvation or semi-starvation.

9. At the present time, there is no valid evidence which relates the characteristic decrease in albumin and increase in the alpha globulins which are observed in many acute and chronic diseases to the protein deficiency of caloric undernutrition which may accompany these diseases.

\section{ACKNOWLEDGMENT}

This work was possible only with the whole-hearted co-operation of the volunteers from Civilian Public Service who served both as subjects and assistants, and all the regular personnel of the Laboratory. Special help in the operation of the electrophoresis apparatus was given by Glen Fisher. Drs. Samuel Wells, Rodney Kendall, Frederick Hoffbauer, Francis Lynch and Russell Wilder provided clinical advice and aid.

\section{BIBLIOGRAPHY}

1. Tiselius, A., A new apparatus for electrophoretic analysis of colloidal mixtures. Tr. Faraday Soc., 1937, 33, 524.
2. Luetscher, J. A., Biological and medical applications of electrophoresis. Physiol. Rev., 1947, 27, 621.

3. Chow, B. F., The correlation between the albumin and alpha globulin contents of plasma. J. Clin. Invest., 1947, 26, 883.

4. Chow, B. F., Allison, J. B., Cole, W. H., and Seeley, R. D., Effect of protein depletion on plasma proteins in the dog measured by electrophoretic analysis. Proc. Soc. Exper. Biol. \& Med., 1945, 60, 14.

5. Zeldis, L. J., Alling, E. L., McCoord, A. B., and Kulka, J. P., Plasma protein metabolism-electrophoretic studies. Chronic depletion of circulating proteins during low protein feeding. J. Exper. Med., 1945, 82, 157.

6. Henschel, A., Taylor, H. L., and Keys, A., The recovery of capacity for physical performance following experimental malaria in man. To be published.

7. Gibson, J. G., II, and Evelyn, K. A., Clinical studies of the blood volume. IV. Adaptation of the method to the photoelectric microcolorimeter. J. Clin. Invest., 1938, 17, 153.

8. Taylor, H. L., Brozek, J., Henschel, A., Mickelsen, O., and Keys, A., The effect of successive fasts on the ability of men to withstand fasting during hard work. Am. J. Physiol., 1945, 143, 148.

9. Keys, A., Human starvation and its consequences. J. Amer. Dietet. A., 1946, 22, 582.

10. Henschel, A., Mickelsen, O., Taylor, H. L., and Keys, A., Plasma volume and thiocyanate space in famine edema and recovery. Amer. J. Physiol., 1947, 150, 170.

11. Keys, A., Henschel, A., and Taylor, H. L., The size and function of the human heart at rest in semistarvation and in subsequent rehabilitation. Amer. J. Physiol., 1947, 150, 153.

12. Longsworth, L. G., Recent advances in the study of proteins by electrophoresis. Chem. Rev., 1942, 30, 323.

13. Tiselius, A., and Kabat, E. A., Electrophoretic study of immune sera and purified antibody preparations. J. Exper. Med., 1939, 69, 119.

14. Keys, A., A rapid micro-Kjeldahl method. J. Biol. Chem., 1940, 132, 181.

15. Armstrong, S. H., Jr., Budka, M. J. E., and Morrison, K. C., Preparation and properties of serum and plasma proteins. XI. Quantitative interpretation of electrophoretic schlieren diagrams of normal human plasma proteins. J. Am. Chem. Soc., 1947, 69, 416.

16. Dole, V. P., Watson, R. F., and Rothbard, S., Electrophoretic changes in the serum protein patterns of patients with scarlet fever and rheumatic fever. J. Clin. Invest., 1945, 24, 648.

17. Dole, V. P., and Emerson, K., Jr., Electrophoretic changes in the plasma protein patterns of patients with relapsing malaria. J. Clin. Invest., 1945, 24, 644.

18. Guttman, S. A., Potter, H. R., Hanger, F. M., Moore, D. B., Pierson, P. S., and Moore, D. H., Sig- 
nificance of cephalin-cholesterol flocculation test in malarial fever. J. Clin. Invest., 1945, 24, 296.

19. Luetscher, J. A., Jr., Electrophoretic analysis of the proteins of plasma and serous effusions. J. Clin. Invest., 1941, 20, 99.

20. Malmros, H., and Blix, G., The plasma proteins in cases with high erythrocyte sedimentation rate. Acta med. Scandinav., 1946, Suppl. 170, p. 280.

21. Barr, D. P., and DuBois, E. F., The metabolism in malarial fever. Arch. Int. Med., 1918, 21, 627.

22. Grossman, C. M., Sappington, T. S., Burrows, B. A., Lavietes, P. H., and Peters, J. P., Nitrogen metabolism in acute infections. J. Clin. Invest., 1945, 24, 523.

23. Boyd, M. F., and Proske, H. O., Observations on blood proteins during malaria infections. Am. J. Trop. Med., 1941, 21, 245.

24. Ghosh, B. N., and Sinton, J. N., Quantitative changes in the proteins of the blood sera of monkeys infected with malarial plasmodia. Rec. Malaria Survey India, 1935, 5, 173.
25. Seibert, F. B., Seibert, M. V., Atno, A. J., and Campbell, H. W., Variation in protein and polysaccharide content of sera in the chronic diseases tuberculosis, sarcoidosis and carcinoma. J. Clin. Invest., 1947, 26, 90.

26. Dole, V. P., and Rothbard, S., Electrophoretic changes in the serum of a patient with rheumatoid arthritis. J. Clin. Invest., 1947, 26, 87.

27. Keys, A., Mickelsen, O., Henschel, A., Brozek, J., and Taylor, H. L. To be published.

28. Peters, J. P., Nitrogen metabolism in acute and chronic disease. Ann. New York Acad. Sc., 1946, 47, 327.

29. McCann, W. S., The protein requirement in tuberculosis. Arch. Int. Med., 1922, 29, 33.

30. Cannon, P. R., The importance of proteins in resistance to infection. J. A. M. A., 1945, 128, 360.

31. Enders, J. F., Chemical, clinical and immunological studies on the products of human plasma fractionation. X. The concentrations of certain antibodies in globulin fractions derived from human blood plasma. J. Clin. Invest., 1944, 23, 510. 